\title{
HET WOORD KABAYAN EN DE OUDE VROUW.
}

DOOR

\author{
Dr. L. M. COSTER-WIJSMAN.
}

Het antwoord, dat Prof. Berg als ,derde vrager" hoopte uit te lokken met zijn artikel in dit tijdschrift 85 p. 469, ,wat beteekent het woord kabayan?" is tans op voortreffelike wijze gegeven door Dr. W. Aichele, Zs. f. Eingeborensprachen $21 \mathrm{Heft}$ 3, 1931. Het zij echter de eerste vraagster vergund nog enig aanvullend materiaal aan te dragen.

Dr. Aichele leidt O. J. kabayan af van baya, een nevenvorm van wayah, die weliswaar in het Javaans niet bekend is, maar die in elk geval theoreties wel mogelik zou zijn en in het Maleis ook inderdaad voorkomt. In de door hem besproken gevallen schijnt deze afleiding wel de aangewezene. Dr. Aichele wijst op plaatsen in het O. J. Wirataparwa, waar kabayan onbetwistbaar in de betekenis ,zeer oud, oudste" wordt gebruikt, en hij toont aan dat het woord, uityaande van deze betekenis, die van ervaren, bedreven in iets gekregen heeft en tenslotte de speciale betiteling van geestelike beambten is geworden. Ik zou hierbij een plaats willen anhalen uit de Tantri, waar het woord kabayan reeds een titel schijnt te zijn, maar nog duidelik aan zijn betekenis ,oud" gebonden. In de door Brandes, Not. Bat. Gen. 38 gepubliceerde Tantritekst vinden we (p. LXX): „hana pas aram-aram, ikang tuha-tuha pas kabayan”. Brandes vertaalt dit met ,dorpshoofd”, Hooykaas noemt het in zijn referaat waarschijnlik juister ,de schildpadden-oudste" ${ }^{1}$ ). In de verklarende woordelijst, toegevoegd aan zijn onlangs verschenen uitgave van de Tantri Kāmandaka vindt men: ,kabayan — ongeveer : oudste” ${ }^{2}$ ).

Maar met deze vertaling komt men niet in alle gevallen uit. Immers, tot nog toe werd aangenomen, en door Prof. Berg ook expliciet uitgesproken, dat het woord kabayan alleen van personen gebezigd

1) Dr. C. Hooykaas, Tantri, diss. Leiden, 1929.

2) Dr. C. Hooykaas, Tantri Kāmandaka, Bibliotheca Javanica 2, Bandoeng 1931. 
wordt. Het tegendeel kan echter blijken uit de volgende plaats in Roorda v. Eysinga's Handboek, waar we in het 3e boek, 2e deel p. 443, in een beschrijving van bepaalde bossen in Tjirĕbon, aantreffen: „Deze wouden worden met den naam van Kabajan (geheiligde of gezegende wouden) bestempeld". Moet men hier, evenals bij het Soendase babajan (datgene waarop men beslag heeft gelegd, een soort pěmali dus ${ }^{1}$ )) denken aan Prof. Bergs afleiding van bhaya?

Ook komt het woord kabayan nog voor in een andere taal en betekenis dan diegene die tot nog toe het onderwerp van discussie hebben gevormd. En dat is een geval, waar men aan de afleiding van de door Prof. Berg genoemde woordstam bi, bay, vrouwelik, de voorkeur geven zou. De Heer O. L. Helfrich was zo vriendelik mij te wijzen op het in zijn Lampongsche Woordenlijst, Verh. B. G. 45 p. 7 voorkomende kěbajan boenting, waarvan hij als betekenis opgeeft: „naam aan een geschaakt meisje toegekend, zoodra zij in het huis van hare aanstaande schoonouders intrek genomen heeft; kĕbajan, een jonggehuwde vrouw, die nog niet bevallen is. „Dr. J. W. van Royen, die op verzoek van de Heer Helfrich nog eens navraag naar het woord deed, hoorde zowel in Kroë als in de Kĕmĕring, dat kĕbajan is het meisje, zodra zij openlik verloofd is (hetgeen uit den aard der zaak na de schaking plaats heeft) zelfs na haar trouwen, totdat het eerste kind geboren is. Dit kěbajan nu zal men zeker hebben af te leiden van de stam baj, bebaj, vrouwelik. In de Bijdr. tot de kennis van het Midden Maleisch van de Heer Helfrich (Verh. B. G. 53) komt op p. 15 baj voor in de betekenis: moeder, moederdier, waarop ik in dit verband mede attent wil maken.

Prof. Bergs suppositie, dat $\mathrm{Nji}$ Bayan haar naam aan deze stam bay heeft ontleend, wint dunkt mij door het voorafgaande nog aan waarschijnlikheid; iets anders is echter de door hem in geding gebrachte mogelike identiteit van $\mathrm{Nji}$ Bayan met het nenek-kĕbayantype. Enerzijds volgt dunkt mij uit het betoog van Dr. Aichele de etymologiese onwaarschijnlikheid hiervan; anderzijds valt het m.i. ook mythologies niet vol te houden.

De oude vrouw-figuur toch onderscheidt zich principieel van de panakawans en de paranjais. De laatste komen altijd in 't veelvoud voor, de oude vrouw nooit. (Hoogstens heeft zij in verhalen van Selebes wel eens een man gehad). De panakawans leven het leven van de held mee, zij zijn zijn min of meer verwrongen spiegetbeeld; de Oude

1) Cf. hetgeen in mijn proefschrift, Uilespiegelverhalen in Indonesië, Leiden 1929, over dit woord werd aangeteekend (p. 139). 
Vrouw treedt alleen op in een bepaalde episode van het verhaal, speelt haar rol en verdwijnt dan weer, of liever, de held trekt van haar vandaan, want voor haar is juist typies, dat zij aan een bepaalde plaats gebonden is. Ik wees reeds ${ }^{1}$ ) op haar rol van bewaakster van de ingang van de andere wereld, van grensfieguur tussen leven en dood, o.a. ook blijkend uit haar vermogen om doden op te wekken. Sindsdien is door Dr. W. H. Rassers ${ }^{2}$ ) en door Th. B. van Lelyveld ${ }^{3}$ ) gewezen op de mogelike identiteit van de Oude Vrouw-stammoeder met de op het einde ener wajangvoorstelling optredende dansende golekpop. Een episode uit een Tobelorees verhaal ${ }^{4}$ ) is wel waard in dit verband te worden aangehaald: Als de Leguaankoning van het Westen de hand van de dochter van de koning van het Oosten heeft verkregen en zijn feestelike intocht houdt, dan loopt vooraan de stoet de Oude Vrouw, ,al dansende met de handen in de zij”. Dus ook hier bij de uiteindelike verzoening der partijen de dans van de Oude Vrouw.

In verband met deze fieguur is mede van belang een passage in de Damar Woelan-uitgave van v. Dorp, waarop reeds Prof. Hazeu de aandacht heeft gevestigd in het addendum van zijn Nini Towongartikel (T. B. G. 43 p. 104). Damar Woelan is door Menak Djingga gedood en diens gemalinnen trachten met tovergebeden hem weer op te wekken; als het niet lukken wil zegt er een: „Hoe is 't mogelik, anders heeft mijn gebed toch een krachtige uitwerking, doordat nini Bokokan het verhoort”. „Wie is deze nini?” vraagt Prof. Hazeu. Omtrent de etymologie van deze naam laten ons de woordeboeken in het duister, maar het is dunkt me niet te gewaagd om verband te zoeken met bĕngkoek, krom, gebogen, O. J. bongkok, kort van gestalte, bungkut, gebocheld. S. v. bungkut vermeldt het Kaw. Bal. Wb. dat Ibungkut de naam is van het spinnende besje in de maan; in 't Savoenees heet ze běni buku, 't kromme vrouwtje, dat zit te spinnen, voor zich hebbende een tampat met kapas, bewaakt door een kat. (Med. Zend. Gen. 36, p. 29). Is het hier gelegde verband juist, dan zou dus ook nini Bokokan het maanvrouwtje kunnen wezen. Anderzijds toont ze - het een sluit het ander niet uit - verwantschapstrekken met het type van de Oude Vrouw. Immers deze helaas al te korte Damar Woelan passage leert ons, dat ze nini genoemd wordt

\footnotetext{
1) O.c., p. 22 .

2) Deze Bijdra. 88, p. 449.

3) De Javaansche Danskunst, p. 112.

4) Deze Bijdr., 7e volgreeks 7e deel, 1908, p. 132.
} 
en dat ze doden kan opwekken, twee eigenschappen der widadaries (over wier karakter en chtoniese aard uitvoerig is gehandeld door Dr. K. A. H. Hidding $\left.{ }^{1}\right)$ ). De Oude Vrouw nu sluit zich in de verhalen altijd nauw an bij de widadaries; o.a. bewaakt zij de put, tevens ingang van de andere wereld, waar deze komen baden, en verzorgt en beschermt zij ze. Het dunkt mij dus waarschijnlik, dat ook dit „Bocheltje”, nini Bokokan, een verschijningsvorm is van de Oude Vrouw, een nevenverschijning dus van nini Towong.

$\mathrm{Naschrift.} \mathrm{Het} \mathrm{artikel} \mathrm{van} \mathrm{de} \mathrm{Heer} \mathrm{G.} \mathrm{J.} \mathrm{van} \mathrm{Dongen} \mathrm{in} \mathrm{deze}$ Bijdragen, dl. 88 p. 519, kwam uit nadat het bovenstaande reeds ingezonden was. Zijn mededeelingen aangaande de nenek kebajan op p. 583 en vlg. maken mijn veronderstelling omtrent nini Bokokan wel zeer waarschijnlik.

1) Nji Pohatji Sanghjang Sri. diss. Leiden 1929, zie vooral p. 49 en vlg. 